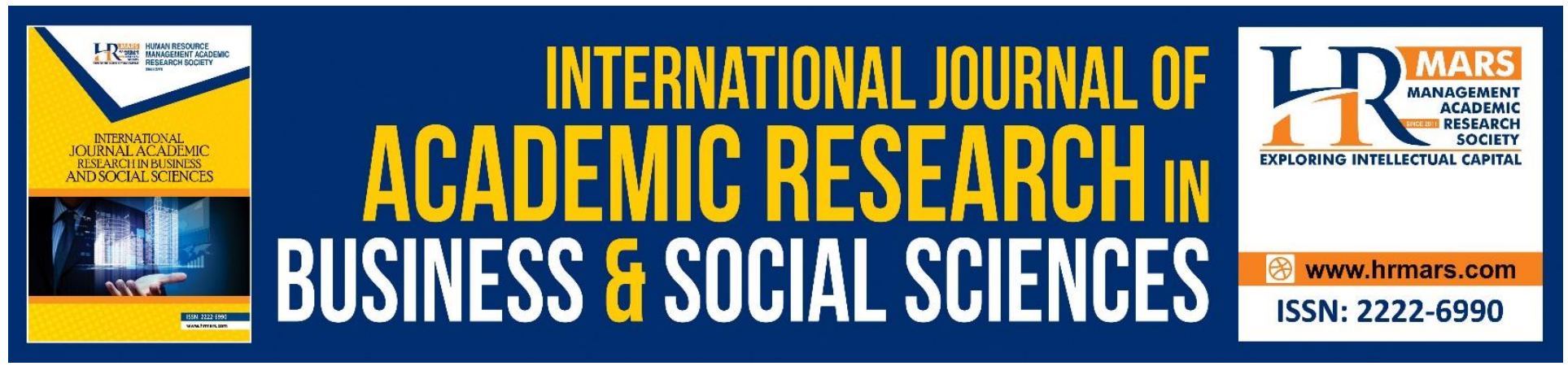

\title{
Fisherman's Knowledge of the Moon Phenomenon in Fishing Activities
}

Nur Aida Athirah Sulaiman

To Link this Article: http://dx.doi.org/10.6007/IJARBSS/v8-i11/4971

DOI: $10.6007 /$ IJARBSS/v8-i11/4971

Received: 07 Oct 2018, Revised: 26 Oct 2018, Accepted: 09 Nov 2018

Published Online: 22 Nov 2018

In-Text Citation: (Sulaiman, 2018)

To Cite this Article: Sulaiman, N. A. A. (2018). Fisherman's Knowledge of the Moon Phenomenon in Fishing Activities. International Journal of Academic Research in Business and Social Sciences, 8(11), 941-949.

Copyright: (C) 2018 The Author(s)

Published by Human Resource Management Academic Research Society (www.hrmars.com)

This article is published under the Creative Commons Attribution (CC BY 4.0) license. Anyone may reproduce, distribute, translate and create derivative works of this article (for both commercial and non-commercial purposes), subject to full attribution to the original publication and authors. The full terms of this license may be seen

at: http://creativecommons.org/licences/by/4.0/legalcode

Vol. 8, No. 11, 2018, Pg. 941 - 949

http://hrmars.com/index.php/pages/detail/IJARBSS

JOURNAL HOMEPAGE

Full Terms \& Conditions of access and use can be found at http://hrmars.com/index.php/pages/detail/publication-ethics 


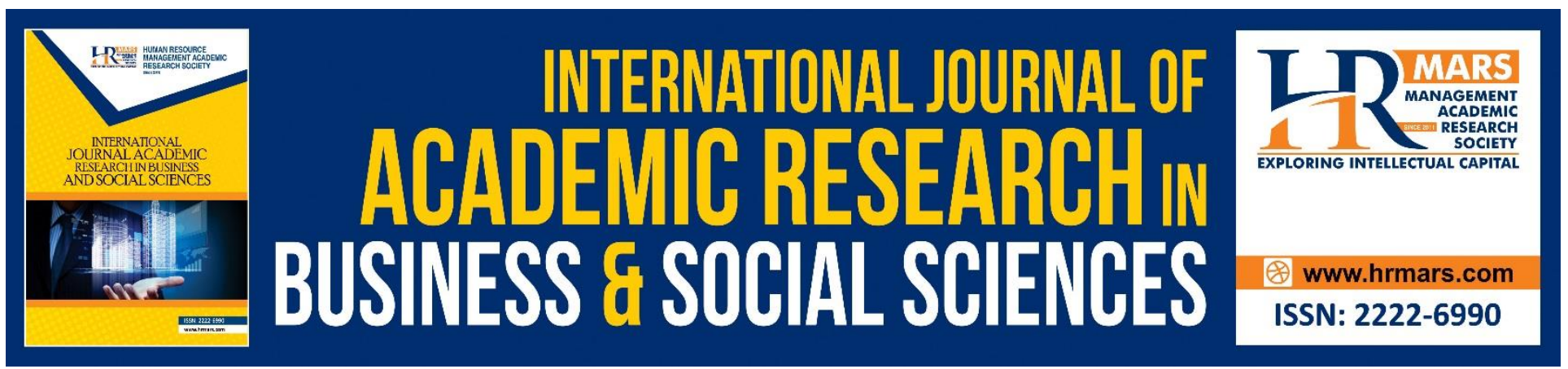

\title{
Fisherman's Knowledge of the Moon Phenomenon in Fishing Activities
}

\author{
Nur Aida Athirah Sulaiman \\ Centre for Islamic Development Management Studies (ISDEV), Universiti Sains Malaysia,11800, \\ Pulau Pinang. \\ Email: aidaathirah_sulaiman@yahoo.com
}

\begin{abstract}
Moon phenomenon affects the society in many daily activities, especially fishery activities. Most fishermen who are making fishery activities as the main source of the farmer's main economy have their own knowledge regarding the moon phenomenon in support of these activities. The question is, how does the moon phenomenon affect fishery activity? How does fisherman's knowledge of moon phenomena affect their fishery activities? To answer this question, two objectives are set out. First, identify the relationship between the phenomenon of the moon and the fishery activity. Secondly, analyzing fisherman's knowledge of the phenomenon of the moon in fishery activities. Documentation methodology used in data collecting methods and qualitative content analysis method was used to analyze the findings that have been collected. Finally, this paper summarizes the discussions that moon phenomenon such as the phases of the moon and the brightness of the moon affect the tides and indirectly affect fishery activities such as fish breeding time, fish season is readily available and the location where the fish are widely available.
\end{abstract}

Keywords: Islamic Astronomical, Moon Phenomenon, Fisherman's Knowledge, Fishery Activity

\section{Introduction}

In early stages of human civilization, Islamic astronomical objects play an important role as a guide for carrying out the daily activities of the community. The community at this stage understands the object of astronomy can be utilized as a time-control, indicating seasonal changes, indicating the availability of food sources, directions and tidal forecasts (Hamacher, 2012). The development of human civilization at the placement level makes humans begin to live in a particular area and carry out activities such as fishing activities. Hence, daily activities of a society, especially fishery activities, are largely influenced by the phenomenon of the moon. Most of the fishermen who make their fishing activities as their main economic resources have their own knowledge regarding the phenomenon in helping this activity. 
INTERNATIONAL JOURNAL OF ACADEMIC RESEARCH IN BUSINESS AND SOCIAL SCIENCES Vol. 8, No. 11, Nov, 2018, E-ISSN: 2222-6990 @ 2018 HRMARS

The question is, how does the moon phenomenon affect fishery activity? How does fisherman's knowledge of moon phenomena affect their fishery activities? To answer this question, two objectives are set out. First, identify the relationship between the phenomenon of the moon and the fishery activity. Secondly, analyzing fisherman's knowledge of the phenomenon of the moon in fishery activities. Documentation methodology used in data collecting methods and qualitative content analysis method was used to analyze the findings that have been collected.

In total, this paper discussions are divided into four main sections. First, the influence of the moon phenomenon on fishery activity. Second, the knowledge of fishermen in fishery activities. Third, fishermen knowledge analysis on influence of month phenomenon in fishery activities. Fourth, the conclusion.

\section{The Influence of Moon Phenomenon on Fishery Activities}

Environmental changes such as changes in the phases of the moon, tides, season's changes and circadian ${ }^{1}$ rhythms affect the behavior of marine life (Pulver, 2017). Scientific studies have been conducted and the findings found that the moon cycle and the tides are in line with living things from primitive levels as well as to marine species (Tessmar-Raible, Raible, \& Arboleda, 2011). In 1926 a theory was produced by Knight to see the impact of maritime life changes especially fish (Bussolini, 2016). Based on this theory, Knight combines the information's on moon, sun and tidal to predict the time the fish tend to be active and this makes it easier for fishermen to catch fish (Bussolini, 2016). Knight's theory is confirmed by him based on a fishing report that has been carried out and found that $90 \%$ of fishing was conducted during the dark moon (new moon phase) (Pulver, 2017). The Solunar Theory introduced by Knight is useful as an indication of fishing activities in the sea as well as rivers (Bussolini, 2016).

To date, many studies have been conducted to see the effects or effects of phenomena on marine life. For example, a study on moon phenomena with coral reefs conducted by Sponaugle and Pinkard in 2004. They found that there are influence of the phases of the moon with breeding-coralreef-fish species such as blue-headed wrasse (Thalassoma bifasciatum). This study examines the condition of fish larvae during the first-quarter moon phase and third-quarter phase phases. In addition, a study on moon phenomena with coral reefs conducted by Pulver in 2017 on which the study discovers some coral reef species. Based on this study, finding the full moon and new moon phenomena only affect the number of catches of certain species of coral reef fish.

The study of moon phenomena on fish catches has also been studied in the waters of Barra do Paraguacu, Brazil by Reis-Filho, Barros, Da Costa, Sampaio and De Souza in 2011. In this study, the rate of catching of tropical tidal seas in Brazil is higher during tidal and full moon conditions and the weight of fish is higher. Significant differences can also be identified in terms of the number of species and the quantity of fish between bright moon and dark moon. The number and biomass of the fish are also different during high tides and tides.

In addition, the effects of the phenomenon of phases of the moon on the species mackerel (Rastrelliger spp.) first-found by Bleeker in 1851 has been studied by Yonvitner, Aziz, Kumi and

\footnotetext{
${ }^{1}$ Circadian rhythms are also known of the biological cycle of a living body.
} 
Pujiastuti (2009). In this study, mackerel fishing was lower during the bright moon in contrast to the catches carried out in other phases of the moon because there is a relationship between optimum light intensity and the fishery activity. However, the findings of a study conducted by Yonvitner, Aziz, Kumi and Pujiastuti (2009) is different from the species of fish surveyed in the study of Reis-Filho, Barros, Da Costa, Sampaio and De Souza (2011) and found that the fish catch is higher during the bright moon of the full moon.

The moon phenomenon not only affects the living that lives in the sea but also the living being in the mangroves. Ramos, Barletta, Dantas, Lima and Costa (2011) examine the effects of the phases of the phases of the moon on the composition of fish that live in the mangroves. In this study, it is proven that the species and weight of fish in the early months of the month (dark moon) are higher than the other phases of the moon.

Scientifically, every living thing on Earth has its own biological cycle and responds to the changing light and ambient temperature (Ikegami, Takeuchi \& Takemura, 2014). Therefore, the moon phenomenon indirectly affects the biological cycle of a living species including fish. There are three types of moon phenomena closely related to the moon cycle system (Ikegami, Takeuchi \& Takemura, 2014). First, full moon cycle, second, semi-month and third cycle, tidal cycle. The full moon cycle involves a recurring periodic change of 1 month interval. The semi-monthly cycle is a periodic activity that spans 14.7 days. Tidal cycles involve month-related activities, which are closely related to the tidal cycle daily and due to the combined effects of gravity applied by the moon and the sun and the rotation of the earth (Ikegami, Takeuchi \& Takemura, 2014).

Each species breeds according to its own reproductive cycle month. For species that multiply by the full moon cycle, the oocytes in the ovary will mature during certain phases of the species that reproduce on a full moon cycle. While for those who multiply according to the semi-monthly cycle of oocytes maturation will occur at high tide, and the species that reproduce according to oocytes maturity cycle will occur during daylight tide. This proves that biological conditions in fish affect the fish breeding activity. For example, the melatonin hormone in the fish reacts to night-light, magnetic fields and tidal cycles (Takemura, Rahman and Park, 2010). Therefore, this proves that each species has a unique reaction system based on the surroundings.

According to Colin (2012) the understanding of how breeding fish groups occur in certain areas and times are only understood at the basic level. Fish breeding in groups is only known in depth by fishermen based on phases of the moon or season. This knowledge helps fishermen to increase fishing rates at certain locations and times. Their knowledge today is known as local knowledge.

\section{Fisherman's Knowledge in Fishery Activities}

Based on previous discussion, it appears the phenomenon of the moon links to fishing activities. In this section, the knowledge of fishermen especially on the phenomenon of the moon in carrying out fishery activities will be discussed. The phases of the moon, the tides, the seasons, the phases of fish life, the wind and the rainy season that occur repeatedly give guidance to fishermen at sea and also on land when and how to descend to the sea (Silva, 2005). Most fishermen know the movement of sea-life differs from year to year based on habitat, season, weather, moon phases and other factors (Johannes \& Neis, 2007). 
The Bugis's fishermen community in Balobaloang has their own knowledge of the moon and the tidal water (Ammarell, 1999). For this society, when they find that the moon is rising in the region, the tide will rise. When the tide begins to rise, the watercourse will move from west to east or the flow of water moves in the direction of the moon. Next, the moon goes down west, the water will begin to recede, and when the water starts to recede, the water stream will move from east to west or the flow of water moves in the direction of the moon. This tide and tidal movement is important to ensure the best time to catch fish.

The fishermen in Malawi have expertise based on their experience of interpreting a natural sign to forecast weather to increase the effectiveness of their fishing operations (Nsiku, 2007:). The natural sign is for example, the influence of moon cycle, current or wave. Fishermen's knowledges are not only involving the knowledge of the moon phenomenon but also all-natural things that can help their fishery activities. In the Vanuatu Islands, experts have identified the exact time to catch fish. Optimum tidal volatility coincides with the selected phase of the moon for migratory fish from deep aquatic areas to coral reef areas. The optimal reef deposition season is also determined by the annual tidal cycle where the reefs are fully exposed during the day. (Hickey, 2007)

In addition, fishermen in the Andaman Sea have a good knowledge of tides that can be applied in their fishing activities (Rajamanickam, 1997). They also know that the new moon and the full moon are where rough sea takes place. They will come down to the sea at the time between the full moon and the new moon because the sea is calm. In addition, the knowledge of fishermen in Patos Lagoon also knows that during the bright moon the gelama fish is difficult to catch. They argue that the moon also affects the timing and success of catching seafood. The full moon is suitable for catching shrimp but not gelama fish. The fishermen argue that during the bright moon, gelama fish is active and hard to catch. (Kalikoski \& Vasconcellos, 2007). In addition, the last-quarters of month phase is suitable for fishing. In May, the mackerel will lay eggs, and this is the best time to catch the fish (Kalikoski \& Vasconcellos, 2007).

Full moon time is not a suitable time for catching salmon. For example, in a fishing community in British Columbia, there is an area known as oom piilts. This area is popular with fish because of tidal currents. Fishermen need to know about the seawater flow because the moon and tides are the most important indicator to know when the fish started to migrate. (Klah-Kist-Ku-Is \& Lucas, 2007). Fishermen in this area know that the best time to catch salmon is two days before the full moon and two days after the full moon. In addition, fishermen in Gaya Island, Sabah say that if the moon is bright, most fishermen do not go down to the sea to go fishing because the moonlight causes the fish movement to be scattered and fish will be able to see the nets (Md. Shah \& Selamat, 2015). However, the bright moon is suitable for catching squid. The fishermen community in Kupa, Barru District, in Sulawesi Region believes that bright moon is the best time for catching squids and the results show a positive impact. (Bahri, 2014).

The fisherman's knowledge about the phenomenon of the moon resulting in production of a calendar that guides the fishermen for a Polynesian community based on the Polynesian calendar which has 29 days out of 30 days using the cycle (Gonzales, 1984). In addition, the use of calendar based on the moon is also used in Javanese society. For the calendar of Javanese people, many fish appear in the sea around 15 days of the month to the beginning of the following month. Fish season changes on a cycle basis for three months without being tied to the calculations of the moon in the 
calendar. For example, three months of fish are easy to get, the next three months the fish is hard to get, and this cycle is repeated (Singgih Tri Sulistiyono, 2014).

In addition, in the Palau community there is a traditional calendar of months used by fishermen in the area. The traditional calendar month Palau community is closely related to the selection day and the optimum month for fishing. In this calendar, the cycle of the moon repeats six times, when the wind blows from the east and the moon cycle is repeated six times, when the wind blows from the west. Next, when the moon goes north, the wind blows from the east and during the east winds, the crescent point of the moon will point northwards (Takeda \& Mad, 1996). The wind blowing direction, wave condition, tidal wave, water conditions that can determine the best time and fish species to be obtained can be referred to in this calendar (Takeda \& Mad, 1996).

In addition, moon-based calendars also affect the movement of fish flows for the Hawaiian community. Moon phases are used to predict fishing activities (Poepoe, Batram \& Friedlander, 2007). This forecast results in a calendar of months which is used as a tool for predicting fishing activities. To date the modern Hawaiian community still uses the moon calendar as a reference (Poepoe, Batram \& Friedlander, 2007). The moon calendar emphasizes natural processes that repeat at different time scales: seasonal, monthly, and daily (Poepoe, Batram \& Friedlander, 2007). The community can develop a calendar that identifies the spawning periods of major fish species by observing the behavior of fish spawning and size of fish and breeding conditions, (Poepoe, Batram \& Friedlander, 2007). For the Hawaiian community, traditional knowledge of fishing is used to avoid interfering with the nature of this species by identifying the reproductive periods of major species sources (Poepoe, Batram \& Friedlander, 2007).

Furthermore, fishermen's fishery community in South Brazil is used in small-scale fishermen at Patos Lagoon resulting from local fishing experience (Kalikoski \& Vasconcellos, 2007). The Fisheries calendar in Patos Lagoon is influenced by the Saltwater intrusion, which is the movement of freshwater to freshwater and rainfall (Kalikoski \& Vasconcellos, 2007). According to fishermen at Patos Lagoon, the best season to catch fish is when the level of estuarine bait is at an ideal state during October to December. (Kalikoski \& Vasconcellos, 2007). Shrimp season is identified when the estuary area is swiftly replaced by salt water. (Kalikoski \& Vasconcellos, 2007). In addition, based on the calendar, January to May is the time to catch fish and shrimp at sea, July to May is the catfish fishing season (Kalikoski \& Vasconcellos, 2007).

\section{Analysis of Fishermen Knowledge's Influence On The Moon Phenomenon in Fishery Activities}

Most of the fishermen are aware of the diverse distribution of life in the sea from year to year based on habitat, season, weather, moon phases and other factors (Johannes \& Neis, 2007). Based on a discussion of the influence of the moon phenomenon and fishery knowledge on fishery activities, there is a clear correlation between these two relationships. Firstly, the knowledge of the time of fish breeding, secondly the knowledge of the location of the fish is abundant and the knowledge of the fish season is easily obtainable.

First, the knowledge about the time of fish breeding. Each species of fish has a certain period to reproduce. The period of reproduction varies due to biological cycles in the fish. Biological cycles of fish species are influenced by surrounding conditions such as light and temperature factors. Consequently, there are species of fish that reproduce in a periodic cycle of 1 month and there are 
types of fish that reproduce periodically 14.7 days. In addition, there are also fish that reproduce by tidal cycle. Knowledge of the time of fish breeding is important to ensure the maturity of the fish larvae to ensure the rate of catching fish somewhere high and does not disturb the natural state of certain fish species (Poepoe, Batram \& Friedlander, 2007). Natural disruption to this life can indirectly cause extinction to the species.

In addition, this breeding time is also important as there are some species of fish that breed in groups. Group fish breeding is only known in depth by fishermen known by the phases of the moon or season. This knowledge helps them to increase fishing rates at certain locations and times (Collin, 2012). This knowledge is also assisted by knowledge of fishermen about the state of light of the moon. During the full moon, the light is light in shallow water and most fish are easily visible and different during the new moon, when the night is dark.

Secondly, knowledge of the location of many fish. The knowledge of the location of the fish is easily recognizable based on species of fish in groups. For example, coral reef collection occurs at most during the year over several days during the new or full moon months, although each species has a longer collection period (Ruddle, 1994). The prediction of fish collection time is not merely referring to the day and month it will occur, but also depending on the tidal of tides. (Ruddle, 1994). This knowledge is important to predict to obtain a high catch of fish for certain fish species. (Ruddle, 1994). The knowledge of fishermen on the location of these fish is important because in order to ensure the fishermen who go down to the sea can catch fish in large numbers and fishing activities become more productive. In addition, knowing the location of this fish is also important for fishermen to catch the desired species of fish.

Thirdly, the knowledge of the fish season earned. Each species of fish has certain seasons in an area of water. This is closely related to the fish breeding process. There are easily accessible fish during bright moon, some are easily found during the dark months, some are easily available during high tide and some are easily available during low tide.

For example, in Siquijor Island the fishermen acknowledge that in the full moon phase of the fish is difficult to obtain (Bucol, 2016). Ecologically this happens because of the decline in oxygen content due to the surrounding environment, for instance the circulation of the weak water cycle and the warmth of the sea-water temperature, when there is occurrence tide at bay during the day (Bucol, 2016). In monsoon transition season, most of the algae from the flat reef will be eroded by the current and the waves and finally taken to the bay and eventually the lagoon will be eroded. When this happens, hypoxia will occur where the oxygen content decreases and causes death to the fish.

\section{Conclusion}

In short, fishermen's knowledge of moon phenomenon helps fishermen to understand the natural sign to forecast weather to increase the effectiveness of their fishing operations (Nsiku, 2007). Hence fishermen's knowledge of fishery activities is important to ensure the sustainability of fishing in an area and to avoid fishing before the fish reach maturity and adulthood. 
INTERNATIONAL JOURNAL OF ACADEMIC RESEARCH IN BUSINESS AND SOCIAL SCIENCES

Vol. 8, No. 11, Nov, 2018, E-ISSN: 2222-6990 @ 2018 HRMARS

\section{Acknowledgement}

This paperwork is part of the research titled Etno-Falak Dalam Aktiviti Maritim [(RUI)1001/CISDEV/8016019] and has been funded by the Research University Individual (RUI) Grant, Universiti Sains Malaysia (2017-2019).

\section{Corresponding Author}

Nur Aida Athirah Sulaiman

Centre for Islamic Development Management Studies (ISDEV)

Universiti Sains Malaysia,11800, Pulau Pinang.

Email: aidaathirah_sulaiman@yahoo.com

\section{References}

Ammarell, G. (1999). Bugis navigation. Yale University Southeast Asia Studies.

Bucol, A.A. (2016). Diminishing sustainability of traditional fishing practices in Siquijor Island, Central Philiphines. Traditional Marine Resource Management And Knowledge. April, 36, 3-12.

Bussolini, J. (2016). Fishing Different, Techniques for Improving Success. Bloomington: Author House Publisher

Colin, P. L. (2012). Timing and location of aggregation and spawning in reef fishes. In Reef fish spawning aggregations: Biology, research and management (117-158). Springer, Dordrecht.

Gonzalez, M. E. (1984). The archaeoastronomy and ethnoastronomy of Easter Island (Doctoral dissertation, California State University, Long Beach).

Hamacher, D.W., 2012. On the Astronomical Knowledge and Traditions of Aboriginal Australians. Doctor of Philosophy Thesis, Department of Indigenous Studies, Macquarie University, Sydney, Australia.

Hickey, F.R. (2007). Traditional marine resource management in Vanuatu: world view in transformation. Fishers' Knowledge in Fisheries Science and Management. Haggan, N., Neis, B. and Baird, IG (eds). UNESCO, Paris, 112-131.

Ikegami, T., Takeuchi, Y., \& Takemura, A. (2014). Lunar Clock in Fish Reproduction. In Annual, Lunar, and Tidal Clocks (pp. 163-178). Springer Japan.

Md. Shah, J \& Selamat, N. H. (2013). "Tangkapan banyak kerana tuah?”: pengetahuan tempatan dan amalan peribumi oleh nelayan bandar di Pulau Gaya, Kota Kinabalu, Sabah. DIm. Nazarudin Zainun (pytg.). Antropologi dan Sejarah dalam Kearifan Tempatan (101-114). Pulau Pinang: Penerbit Universiti Sains Malaysia.

Johannes, R. E., \& Neis, B. (2007). The value of anecdote. Fishers' Knowledge in Fisheries Science and Management. Haggan, N., Neis, B. and Baird, IG (eds). UNESCO, Paris, 41-58.

Kalikoski, D.C. \& Vasconcellos, M. (2007). The role of fishers' knowledge in the co-management of small-scale fisheries in the estuary of Patos Lagoon, Southern Brazil. Dalam Haggan.N, Barbara, N. dan Baird, I.G., Fisher's knowledge in fisheries science and management. Perancis: United nations Educational, Scientific and Cultura Organization.

Klah-Kist-Ku-Is \& Lucas, S. (2007). Life supports life. Fishers' Knowledge in Fisheries Science and Management. Haggan, N., Neis, B. and Baird, IG (eds). UNESCO, Paris, 37-45 
INTERNATIONAL JOURNAL OF ACADEMIC RESEARCH IN BUSINESS AND SOCIAL SCIENCES

Vol. 8, No. 11, Nov, 2018, E-ISSN: 2222-6990 @ 2018 HRMARS

Nsiku, E. (2007). Indigenous technical knowledge of Malawian artisanal fishers. Fishers' knowledge in fisheries science and management, 215-222.

Poepoe, K. K., Bartram, P. K., \& Friedlander, A. M. (2007). The use of traditional knowledge in the contemporary management of a Hawaiian community's marine resources. Fishers' knowledge in fisheries science and management, 437.

Pulver, J. R. (2017). Does the Lunar Cycle Affect Reef Fish Catch Rates?. North American Journal of Fisheries Management, 37(3), 536-549.

Rajamanickam, G. V. (1997). Traditionala sea knowledge prevailing among tribes of Andaman and Nicobar Island. Indian journal of history of science, 32(1), 29-46.

Ramos, J. A. A., Barletta, M., Dantas, D. V., Lima, A. R. A., \& Costa, M. F. (2011). Influence of moon phase on fish assemblages in estuarine mangrove tidal creeks. Journal of Fish Biology, 78(1), 344-354.

Reis-Filho, J. A., Barros, F., Da Costa, J. D. A. C., Sampaio, C. L. S., \& De Souza, G. B. G. (2011). Moon and tide effects on fish capture in a tropical tidal flat. Journal of the Marine Biological association of the United Kingdom, 91(3), 735-743

Ruddle, K. (1994). Local knowledge in the folk management of fisheries and coastal marine environments. Folk Management in the World's Fisheries, 161-206.

Silva, G. (2005). The classification of living beings among the fishermen of Piratininga, Rio de Janeiro dlm. Diugues, A.C. (pytg.) Maritime Anthropology in Brazil. Sao Paulo (76-79).

Sulistiyono, S. T. (2014). Mengenal sistem pengetahuan, teknologi, dan ekonomi nelayan Pantai Utara Jawa. Jurnal Agastya, 4(2), 1-24.

Sponaugle, S., \& Pinkard, D. (2004). Lunar cyclic population replenishment of a coral reef fish: shifting patterns following oceanic events. Marine Ecology Progress Series, 267, 267-280.

Bahri, S. (2014). Dinamika pengetahuan nelayan pancing di Kupa, Kabupateb Barru, Provinsi Sulawesi Selatan. Walasuji, 5(2), 253-264.

Takeda, J. \& Mad, P. K. (1996). Traditional Palauan lunar calendar and the fishing gleaning activities on reef flats and/or in lagoons in the Western Caroline Islands, Micronesia. Occasional Papers, 30, 91-106.

Takemura, A., Rahman, M. S., \& Park, Y. J. (2010). External and internal controls of lunar-related reproductive rhythms in fishes. Journal of fish biology, 76(1), 7-26.

Tessmar-Raible, K., Raible, F., \& Arboleda, E. (2011). Another place, another timer: marine species and the rhythms of life. Bioessays, 33(3), 165-172.

Yonvitner, A., Butet, N.A., Pujiastuti, D. (2009). Lunar moon phase terhadap tangkapan persatuan upaya ikan kembung (Rastrelliger spp, Bleeker, 1851) di Pulau Damar, Kepulauan Seribu. Jurnal Perikanan dan Kelautan, 14(1), 70-80. 